\title{
CHAPTER 03: CHEMICAL COMPOSITION OF MAIZE LANDRACES AND THEIR IMPORTANCE TO HUMAN HEALTH
}

Francisco Wilson Reichert Júnior ${ }^{1}$; Carlos Rafael Silva de Oliveira ${ }^{2}$; Afonso Henrique da Silva Júnior ${ }^{3}$; Jéssica Mulinari ${ }^{4}$.

\begin{abstract}
Maize is one of the most cultivated cereals in the world, corresponding to up to $20 \%$ of the total calories consumed by humans. This species has great genetic diversity for plant, ear, and grain characteristics. Besides being a source of protein and carbohydrates, maize may be a source of other important compounds for human health, such as carotenoids with provitamin A activity. Thus, this review aims to present the importance of landrace varieties as a source of important chemical components for human health. Around 500,000 children worldwide suffer from health problems related to lack of vitamin A. A possible solution to increase the levels of provitamin $\mathrm{A}$ in the diet is the biofortification of maize. Landraces varieties of maize can be a tool for the biofortification of maize since they present great genetic variability for several characteristics, among them, higher levels of carotenoids predecessors of provitamin A than commercial varieties. Furthermore, landraces varieties can be an alternative for cultivation in needy communities, since they need less technological input for their cultivation. Thus, studies that seek to study the potential of landraces varieties for the biofortification of maize are essential.
\end{abstract}

Keywords: Maize landraces, Nutrition, Human health, Genetic resources.

\section{Introduction}

Maize is the species with the highest genetic diversity among cultivated crops, with a large number of varieties being identified. Besides, it has a great edaphoclimatic adaptation and can be grown at different altitudes and latitudes. Maize still presents great variability for quantitative and qualitative characteristics, such as reaction to diseases, productivity, the biochemical composition of grains, plant and cycle architecture (PATERNIANI et al., 2000; TEIXEIRA, 2008). This great adaptability allowed the species to spread throughout the national territory, being present in practically all the states of Brazil.

The genetic material available, also known as germplasm, is composed of a set of different types of maize such as sweet, common, or popcorn. Among each type of maize, there are landraces materials (local), improved populations, and exotic materials (NASS et al., 1993; ARAÚJO AND NASS, 2002). There are several terms for landraces, eg. local, traditional, ancient varieties, etc. Harlan (1975) described landrace varieties as populations made up of a mixture of genotypes in which all are reasonably well adapted to the region in which they evolved but present small differences in adaptations to particular conditions within the environment, such as reactions to diseases, pests, competition, abiotic stresses, and nutritional composition (ZEVEN, 1998). In maize, landraces varieties can vary widely in shape and color of grains, ranging from white to almost black. 
ARAÚJO AND NASS, 2002). There are several terms for landraces, eg. local, traditional, ancient varieties, etc. Harlan (1975) described landrace varieties as populations made up of a mixture of genotypes in which all are reasonably well adapted to the region in which they evolved but present small differences in adaptations to particular conditions within the environment, such as reactions to diseases, pests, competition, abiotic stresses, and nutritional composition (ZEVEN, 1998). In maize, landraces varieties can vary widely in shape and color of grains, ranging from white to almost black.

Conserving genetic variability is important for maize, since the production of ancient and landrace cultivars, which is a way of preserving these materials, has been disappearing. This maintenance has been threatened by pressure on producers to adopt improved cultivars. Furthermore, the rural exodus threatens both agriculture and landraces materials themselves (CANCI et al., 2004). The substitution of landrace cultivars for commercial ones brought advantages to the producer, such as greater productivity and homogeneity, however, it brought some problems, among them the higher production costs and the reduction of nutritional quality.

Although much of the maize grain is composed of starch and proteins, there are several other substances, such as anthocyanins and carotenoids, normally related to pigmentation and found with greater abundance in landrace varieties. These compounds have received attention due to their human health benefits. Carotenoids are tetraterpenes, mainly responsible for the yellow and orange colorations of various vegetables. Carotenoids are known to benefit the activity of vitamin A. Anthocyanins are pigments responsible for the purple, blue and red stains in vegetables. Among the biological functions of anthocyanins, can be mentioned the antiinflammatory, anticancer, and antioxidant activities, among others (CEVALLOS-CASALS, et al., 2004; HULSHOF et al., 2007; KUHNEN et al., 2011).

Landraces varieties are not only important for breeding but also have a great socioeconomic role. They are grown in practically the entire national territory, mainly in regions of the predominance of family farming or indigenous and quilombolas since they need less technological inputs, making the cultivation less costly (BARROS et al., 2010; SANDRI and TOFANELLI, 2008).

In this sense, the conservation of maize diversity is important not only for the species itself but also for the human being, since the diversity of landrace varieties contributes to a diversity of compounds important for human health. Thus, in this review, works that show the importance of Landrace varieties of maize to the human diet will be presented, as well as the compounds found in these varieties and their benefits for human nutrition and health. 


\section{Maize landraces}

Maize is probably the cultivated species with the greatest genetic diversity (Figure 1). There are more than 300 known breeds and, within these, thousands of varieties. It is grown practically all over the globe, presenting materials adapted to the most diverse climates and regions: from altitudes of 2,500 $\mathrm{m}$ to sea level and latitudes varying from the extreme north to the extreme south. It is possible to observe this genetic variability for plant, ear and grain characteristics, size, cycle, the chemical composition of the grains, endosperm, and protein quality (PATERNIANI et al., 2000).

Landrace varieties are defined as varieties coming from species that occur in situ, composed of a group of plants within a taxon at the lowest known level, with genetic diversity developed or adapted by the indigenous population, traditional community or traditional farmers, including natural selection combined with human selection in the local environment, which is substantially different from commercial cultivars (BRAZIL, 2015). There are several cultures that present landrace varieties maintained by farmers, such as beans, rice, wheat, maize, among others.

These varieties are important for the breeding of crops, as they have a high potential for adaptation to specific environmental conditions. In general, landrace varieties are less productive than commercial cultivars. However, these materials have great genetic variability and constitute a source of genes that can be exploited in the search for resistance to biotic and abiotic factors, as well as a source of important health compounds (PATERNIANI et al., 2000; ARAÚJO and NASS, 2002; HWANG et al., 2016).

Figure 1. Diversity of Mexican landraces maize varieties.

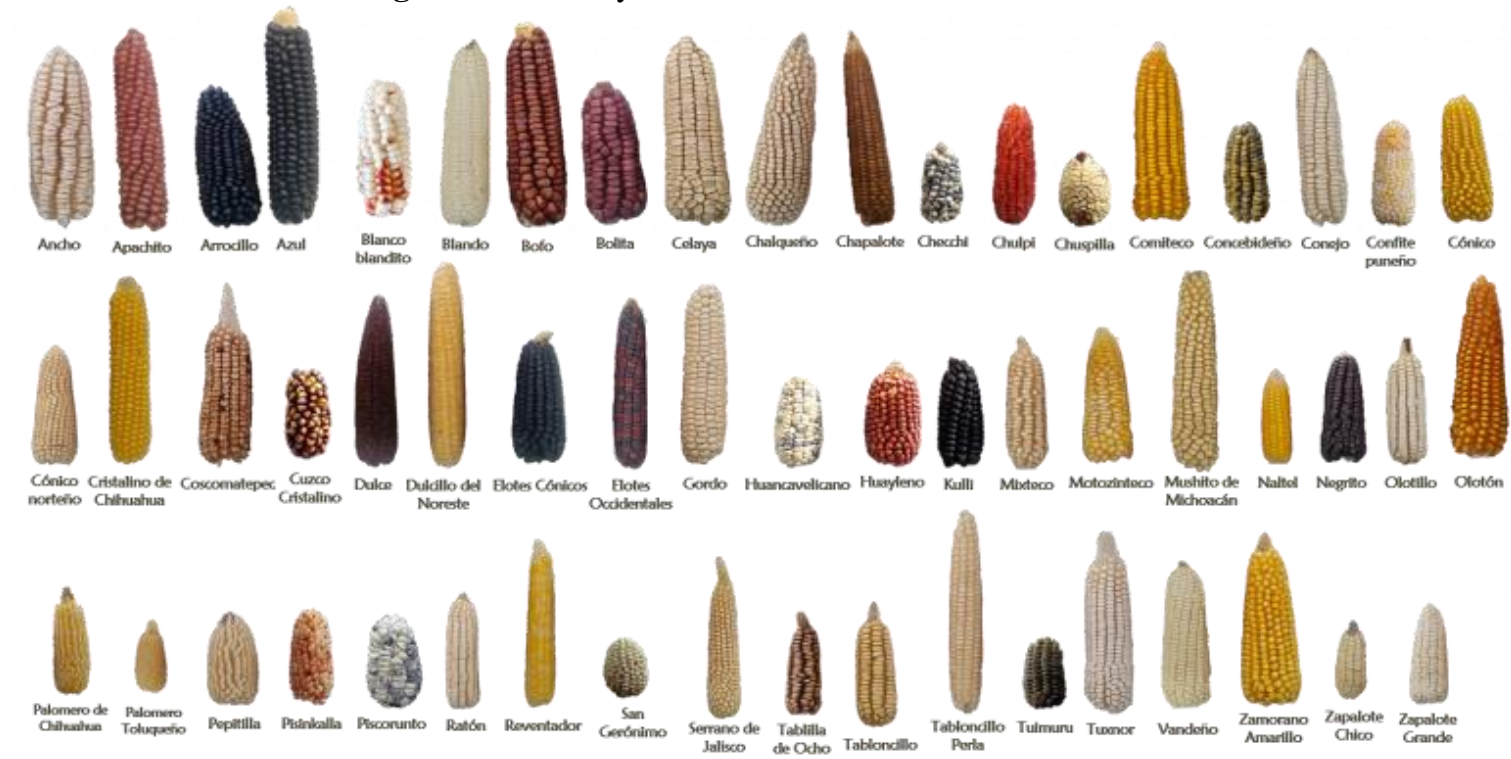

Source: O'Leary, M. CIMMYT (2016). 
The maize kernel is compost of three major parts: the pericarp is the outer layer of the kernel, protects the pericarp against moisture, and the attack of insects and microorganisms, one of the parts of the pericarp is the aleurone layer. The endosperm represents about $80 \%$ of the kernel's dry matter, it is the source of starch (energy) and protein for the germ when the seed is germinating. The germ is the only living part of the kernel, which contains the genetic information, vitamins, enzymes, and minerals for the kernel to develop into a maize plant (POMERANZ, 1982).

There are different forms and compositions of the maize grain endosperm that classify them into different types (Figure 2). According to Brown and Darrah (1985), among the main are:

a) Dent maize: It is characterized by the presence of endosperm with hard starch on the sides and back of the grains, while from the center to the crown it is composed of soft or floury starch, which after drying produces a distinct indentation, in the form of a tooth. It is mainly used for animal feed, however, it is the raw material for many industrialized products and staple foods. Although more than $90 \%$ of its production is destined for animal feed, this type of Maize enters several specialized products through the milling industry. It can reach the market at a high price for certain products due to its whiter starch.

b) Flint maize: This type of maize has a thick and hard endosperm with vitreous starch and a small portion of soft starch in the center. The grains are generally round and smooth. They present better development in temperate regions and are mostly grown in South America (such as Argentina) and southern Europe, where they are used for typical dishes.

c) Popcorn: It is probably the oldest type of maize. It is characterized by an extremely hard endosperm, with only a small portion of soft starch in the center. It is practically a flint maize with small grains. The beans can be pointed or round. It is characterized by the expansion of the endosperm when heated, breaking the pericarp, and exposing the starch. It is mainly used for human consumption as a snack.

d) Sweet maize: It is characterized by a maize that has mutant recessive genes that alter the synthesis of starch in the endosperm, accumulating sugars. When dry, it presents a wrinkled appearance. Among the main mutant genes related to these characteristics are sugary $(s u)$, shrunken $-2(s h 2)$, and Brittle $(b t)$. It is mainly used in the production of canned foods and the sale as fresh maize. 
e) Flour maize: It presents endosperm with almost entirely soft starch. When dry it shrinks completely evenly and does not form the indentation. When dry, they are easy to mill, however, it molds easily when maturing in more humid regions. Its cultivation is more common in the Andean regions of South America.

Figure 2. Endosperm distribution and major parts in five types of maize kernels

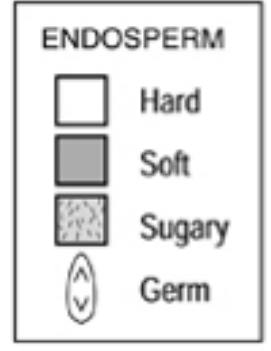

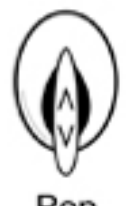

Pop

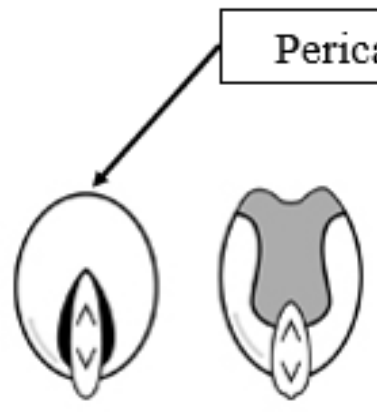

Flint

Dent

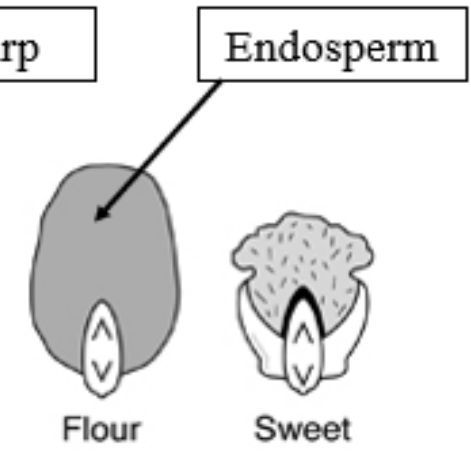

Source: Adapted from Dickerson, (2003).

All of these types of maize have landrace varieties being grown in different places on the planet, including Brazil. In 2013, after conducting a diversity census in the Far West region of Santa Catarina, 1513 local maize populations were found, 1078 of popcorn maize, 337 of dent maize, 61 of sweet maize, and 37 of farinaceous maize. Among the main uses described by farmers, features of agronomic and culinary interest were highlighted, where producers described the preference for landrace maize in the production of typical dishes and family food (COSTA et al. 2016).

These landrace varieties have been widely cultivated independently across the country and have socioeconomic importance for family farming systems (CARVALHO et al., 2004). Thus, the conservation of landrace varieties of maize is associated with the way of cultivation of several families of small farmers in Brazil.

\section{Grain composition and health benefits}

The average bromatological and micronutrient composition of the sweet, popcorn and dent grains of commercial cultivars is shown in Table 1. As the composition of the farinaceous and flint grains are similar to those of the dent grains, they were not included in the table. 
Table 1. Average bromatological and micronutrient composition of popcorn, sweet and dent maize (quantity in

\begin{tabular}{lccccc}
\hline Maize type & Protein & Lipid & Fiber & Carbohydrates & Sugars \\
\hline $\begin{array}{l}\text { Dent } \\
\text { Popcorn } \\
\text { (popped) }\end{array}$ & $10.35 \mathrm{~g}$ & $5.20 \mathrm{~g}$ & $7.0 \mathrm{~g}$ & $75.90 \mathrm{~g}$ & $0 \mathrm{~g}$ \\
Sweet & $12.90 \mathrm{~g}$ & $4.50 \mathrm{~g}$ & $14.5 \mathrm{~g}$ & $77.50 \mathrm{~g}$ & $0.90 \mathrm{~g}$ \\
\hline Maize type & $\mathbf{P}$ & $1.00 \mathrm{~g}$ & $2.0 \mathrm{~g}$ & $15.80 \mathrm{~g}$ & $6.30 \mathrm{~g}$ \\
\hline $\begin{array}{l}\text { Dent } \\
\text { Popcorn } \\
\text { (popped) }\end{array}$ & $300.0 \mathrm{mg}$ & $325.0 \mathrm{mg}$ & $108.0 \mathrm{mg}$ & $5.0 \mathrm{mg}$ & $4.5 \mathrm{mg}$ \\
Sweet & $300.0 \mathrm{mg}$ & $250.0 \mathrm{mg}$ & $80.0 \mathrm{mg}$ & $2.5 \mathrm{mg}$ & $0.10 \mathrm{mg}$ \\
\hline
\end{tabular}

Source: USDA (2020); FAO (2020).

In a $100 \mathrm{~g}$ portion, dent maize has $7.3 \mathrm{~g}$ of fiber, sorghum $6.7 \mathrm{~g}$, wheat $13.1 \mathrm{~g}$, popcorn $14.4 \mathrm{~g}$, and oat $10.1 \mathrm{~g}$. Regarding protein, maize has $10.34 \mathrm{~g}$, sorghum $10.62 \mathrm{~g}$, wheat $9.61 \mathrm{~g}$, and popped popcorn $12.89 \mathrm{~g}$. As for iron, maize has $2.71 \mathrm{mg}$, sorghum $3.36 \mathrm{mg}$, wheat 3.71 $\mathrm{mg}$, roasted meat $0.56 \mathrm{mg}$, egg $1.56 \mathrm{mg}$, and popped popcorn $3.19 \mathrm{mg}$ (USDA, 2020). The main differences in the composition of the grains are related to differences in the shape of the grain and the composition of the endosperm. In the case of popcorn, in a $100 \mathrm{~g}$ portion, it has more protein than the main cereals, more iron than eggs and meat and more fiber than oat. Showing the nutritional validity of this snack.

The protein contents and other components of the grain may vary depending on the genotype and the environment. Uarrota et al. (2013), working with eight landrace varieties of maize, found protein levels ranging from 7.04 to $11.59 \mathrm{~g}$ per $100 \mathrm{~g}$ of grains, while lipids ranged from 3.01 to $5.53 \mathrm{~g}$. These values are relevant when compared to studies using commercial hybrids that found values of protein that ranged from 5.7 to $8.9 \mathrm{~g}$ (ERICKSSON et al., 2001; SCHULZ and BARANSKA, 2007).

Maize is the raw material for food, feed, and many industrialized products, ranging from textile products to the pharmaceutical industry. Maize represents about $15 \%$ of total proteins and $20 \%$ of all calories in human food (FAO, 1992), in addition to being a source of carotenoids (VALLABHANENI et al., 2010; KUHNEN, et al., 2011; MESSIAS et al., 2014). However, the main effort currently concerning the importance of maize in the human diet is in the biofortification of this crop, mainly in aspects related to vitamin A and micronutrients such as zinc and iron (BOUIS AND SALTZMAN, 2017).

Concerning the micronutrients, biofortification efforts have been carried out to increase 
the levels of minerals in the grains. Zinc, for example, has a fundamental role in antioxidant and DNA repair functions, and its deficiency can increase the risk of cancer (MAFRA, 2005; MESSIAS et al., 2013). Maize has an average zinc content of $20 \mu \mathrm{g} \cdot \mathrm{g}^{-1}$, approximately $40 \%$ of the daily requirement for children and lactating mothers (CAKMAK, 2008), requiring the consumption of approximately $350 \mathrm{~g}$ of maize per day to achieve that $40 \%$. Bänzinger and Long (2000) showed the potential of landrace varieties to increase the levels of minerals in maize. When evaluating 1,814 varieties of maize, they found zinc values reaching $57.6 \mu \mathrm{g} \cdot \mathrm{g}^{-1}$. The potential of a large part of the maize germplasm is still unknown, making its characterization essential to find characteristics of interest.

Concerning pigments, landrace maize may be an important alternative in the search for genotypes with higher levels of carotenoids. These compounds are the main source of yelloworange pigments in plants and are classified into xanthophylls (lutein, $\beta$-cryptoxanthin, and zeaxanthin), derivatives of oxygenated hydrocarbons and carotenes ( $\beta$-carotene and $\alpha$ carotene). Some of these substances, such as lutein and zeaxanthin, have antioxidant properties and about 50 carotenoids have provitamin A activity. Provitamin A is linked to several essential functions in the body, such as reproductive functions, vision, growth, and immunity, besides presenting anti-cancer effects, preventing macular degeneration and reducing the risk of diabetes (JASWIR et al., 2011; RODRIGUES-AMAYA, 1997; KOUSHAN et al., 2013; KUHNEN et al., 2011; HWANG et al., 2016).

Although these compounds are present in fruits and vegetables, their presence in grains, such as maize, is of major relevance and should be emphasized due to the importance of this cereal in the human diet worldwide, especially in regions with lower human development indexes, such as some regions of Brazil, Africa and Asia (ZUMA et al., 2018). Besides, there is evidence that indicates that the human consumption of plant metabolites such as carotenoids is below ideal, mainly in poor regions. Another problem is the focus of breeding programs that emphasize, for the most part, productivity as opposed to grain quality, while, due to its importance in the diet, grain quality should be among the priorities. Since maize has good levels of secondary compounds and there is the possibility of increasing its micronutrient levels to combat the deficiency of these nutrients, maize has gained great interest in biofortification programs (ZHU et al., 2008; MESSIAS et al., 2014).

The vast majority of commercial maize varieties grown in the world have values of provitamin A pigments, such as carotenoids, of around $2 \mathrm{mg} \cdot \mathrm{kg}^{-1}$ (HARJES et al., 2008). Based on this and the increased demand for more nutritious and functional foods, landrace varieties can be a source of genes for increasing the levels of carotenoids due to their genetic variability 
for several characteristics (MESSIAS et al., 2014). Table 2 shows studies evaluating landrace varieties and lines of maize regarding their carotenoid content.

Table 2. Content of some of the carotenoids found in studies with landrace varieties and lines of maize.

Range $\left(\mathrm{mg} \cdot \mathrm{kg}^{-1}\right)$

\begin{tabular}{|c|c|c|c|c|}
\hline Authors & No. of varieties & Zeaxanthin & Lutein & $\beta$-Cryptoxanthin \\
\hline $\begin{array}{l}\text { (KUHNEN et al., } \\
\text { 2011) }\end{array}$ & 26 landraces & $0.07-10.7$ & $0.03-3.69$ & $0.01-0.10$ \\
\hline $\begin{array}{c}\text { (HWANG et al., } \\
\text { 2016) }\end{array}$ & $\begin{array}{c}2 \text { landraces } \\
\text { (different locations) }\end{array}$ & $0.05-14.90$ & $\begin{array}{l}0.12- \\
24.99\end{array}$ & $0.08-8.83$ \\
\hline $\begin{array}{c}\text { (MENKIR et al., } \\
\text { 2017) }\end{array}$ & $\begin{array}{l}477 \text { lines in } 2014 \\
\text { and } 496 \text { in } 2016\end{array}$ & $0.0-42.8$ & $0.0-52.9$ & $0.1-9.6$ \\
\hline $\begin{array}{l}\text { (PILLAY et al., } \\
\text { 2011) }\end{array}$ & F2 of different colors & $0.09-11.8$ & $1.1-19.1$ & $0.01-5.4$ \\
\hline $\begin{array}{l}\text { (SWARNO et al., } \\
2014)\end{array}$ & 127 inbred lines & $2.77-14.88$ & $0.01-7.22$ & $1.65-9.71$ \\
\hline
\end{tabular}

The range between varieties it is mainly related to genetic and environmental factors. The same variety can present different values in contents of chemical components due to the change of environment. In the research by Sweley et al. (2012) when studying the effect of hybridity and the environment on biochemical and physical characteristics of popcorn, found that both influenced significantly, having the environment more prominently influenced the mineral composition of grains of popcorn. Changes in the mineral composition of the grains are largely related to the type of soil and availability of nutrients. Thus, studies that evaluate genetics and in which environments each variety best expresses its components are essential for cultivation and use indications (FAO, 1992).

Since maize is one of the most cultivated species in the world, it can be an alternative in places where the consumption of fruits and vegetables is not enough to supply the need for provitamin A compounds. Vitamin A deficiency (VAD) is considered a serious problem in more than 60 countries, mainly in Africa and Asia. The World Health Organization reported that about 250 million preschool children are affected by VAD worldwide. Among the main problems related to hypovitaminosis $\mathrm{A}$ is the degeneration of the optic system, leading about half a million children to blindness in pre-school age (WHO, 200?). The great genetic variability of maize for the levels of carotenoids, as shown in Table 2, can be one of the tools to find genes 
that can be used in breeding programs to increase the levels of provitamin $\mathrm{A}$ in cereals (HARJES et al., 2008; WURTZEL et al., 2012).

Since carotenoids are closely related to grain color, it is necessary to understand how it works and how this characteristic is regulated. The yellow color and its variations are related to the carotenoid metabolic pathway, while the red and purple colors are related to the anthocyanin biosynthesis. The white color is produced by the lack of pigments from any of the previous paths. The production of these colors requires numerous genes, from structural to regulatory genes. Only the genes related to carotenoids can express the coloring on the endosperm, while anthocyanins are related to pigmentation of the pericarp, more specifically the aleurone. These interactions can be seen in pigment extraction studies. For example, when working with landraces of maize in southern Brazil, Kuhnen et al. (2011) identified that the varieties in which the carotenoids were responsible for the coloring (such as Língua de Papagaio and Palha Roxa) have low amounts of anthocyanins, having pigmented endosperm and colorless pericarp, while varieties with less pigmentation in the endosperm (such as Roxo 29 and Roxo 41) have greater amounts of anthocyanins, having colorless endosperm and pigmented pericarp. The main genes related to the final color of the grain and their combinations are shown in Table 3 (FORD, 2000).

Table 3. Summary of genes related to maize grain color.

\begin{tabular}{lccccc}
\hline Gene Type & Symbol & Gene Name & Symbol & Phenotype & Metabolic Pathway \\
\hline Color Gene & $P r$ & Red & Prl & Purple aleurone & Anthocyanin \\
& & Aleurone1 & & & \\
Color Gene & $R r$ & & $p r l$ & Red aleurone & \\
& $r$ & Colored1 & $R l(R-r)$ & Colored aleurone & Anthocyanin \\
Color Gene & $C^{l}$ & Colored & $C 1-I$ & Colorless aleurone & Anthocyanin \\
& & Aleurone1 & & & \\
& $C$ & & $C 1$ & Colored aleurone & \\
Color Gene & $Y$ & White1 & $Y 1$ & Yellow endosperm & Carotenoid \\
& $y$ & & $y 1$ & White endosperm & \\
\hline
\end{tabular}

Source: Ford (2000).

While the final color of the grains is related to four major genes, carotenoid biosynthesis consists of several steps governed by several genes. For the biofortification of maize, it is 
necessary to understand the biochemical synthesis and identify the main genes involved in the biosynthesis of provitamin A (MAQBOOL et al., 2018). Typically, characteristics like these are governed by more than one gene, being considered quantitative characteristics, which are more complex to work in breeding programs. However, identifying this quantitative effect is essential to find out which genes are linked to this trait and which is the best breeding method to adopt.

Thus, the search for potential genes involved in the production of provitamin $\mathrm{A}$ is essential (MAQBOOL et al., 2018). A summary of the carotenoid biosynthesis is shown in Figure 3. Carotenoid biosynthesis is composed of several key points that are governed by different enzymes/genes, among them: phytoene synthase 1 (PSY1), phytoene desaturase $(P D S), \zeta$-carotene desaturase $(Z D S)$, lycopene $\beta$-cyclase $(L C Y B)$, lycopene $\varepsilon$-cyclase $(L C Y E)$ and $\beta$-carotene hydroxylase 1 (CRTRB1). In addition to identifying the genes, understanding the production efficiency of provitamin A is also important, since different genes can have different production efficiencies.

Figure 3. Summary of carotenoid synthesis. Enzymatic reactions are represented by arrows. Dotted lines indicate that there are steps not shown.

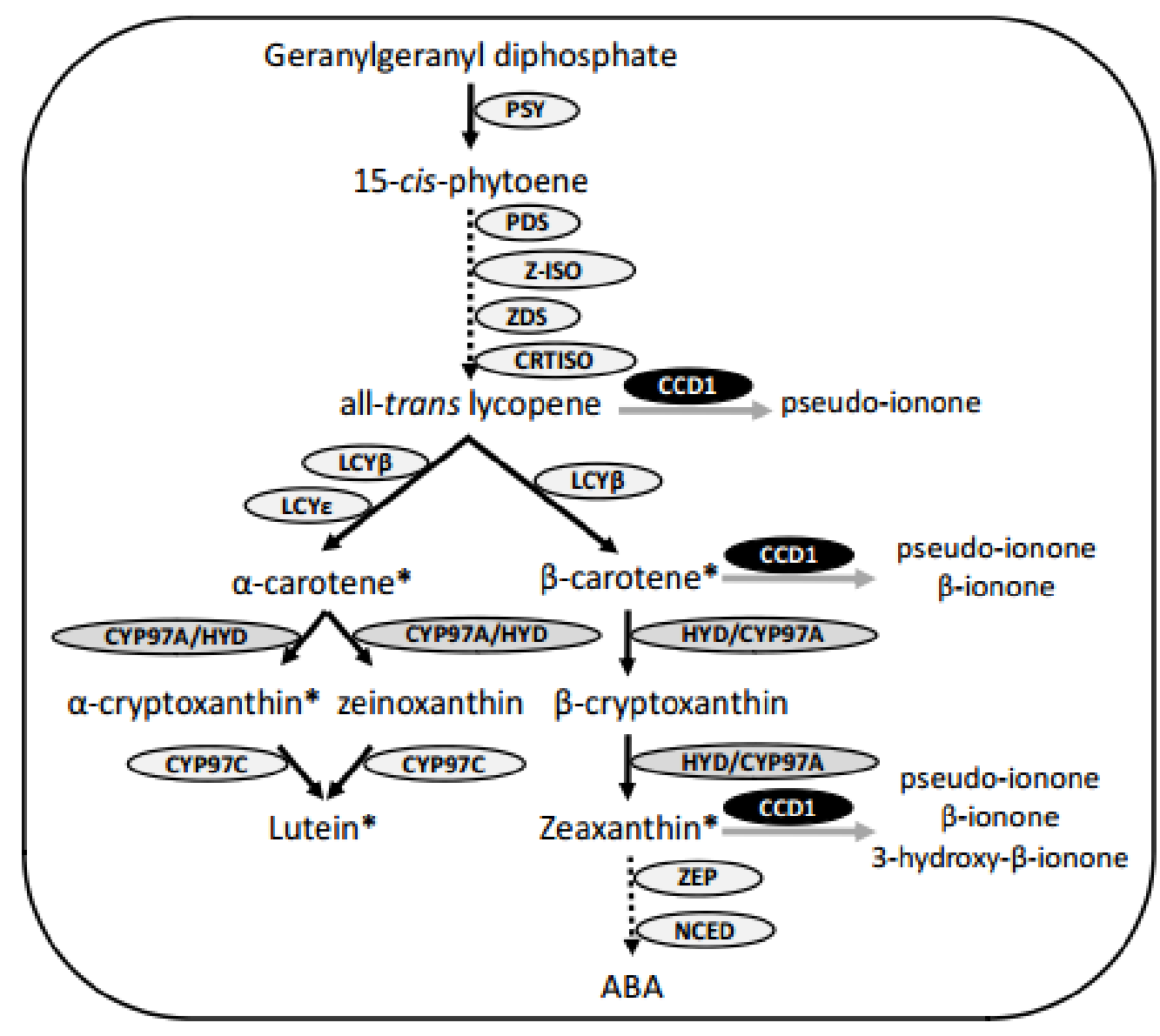

Source: MESSIAS et al. (2014). 
Messias et al. (2014), studying landrace varieties of maize, observed that the levels of carotenoids ranged from 10.03 to $61.50 \mu \mathrm{g} \cdot \mathrm{g}^{-1}$, with the highest levels in yellow-orange varieties. Furthermore, they identified that the expression of PSY1 (phytoene synthase) showed a positive correlation with the total content of carotenoids, and they also identified two varieties with potential for biofortification of maize to provitamin A. Harjes et al. (2008) found a positive correlation between the gene LCYE and the levels of $\beta$-carotene and $\beta$-cryptoxanthin in maize. Yan et al. (2010) observed a correlation between the CRTRB1 gene and the increase in $\beta$ carotene and its subsequent conversion to $\beta$-cryptoxanthin and zeaxanthins. Studies like these show the importance of genetic variability in the search for genes of interest for the improvement and biofortification of the species.

\section{Final Consideration}

Since maize is a crop of world importance in human nutrition, the conservation of the genetic diversity of this species is essential for its adaptation to climate changes, food supply and food security. In the case of maize biofortification, especially for provitamin A, landrace varieties are an important source of genes. Also, this varieties are important source of food and economic income for many small farmers, being used for food and feed in their farms. Thus, the conservation of these materials is fundamental for the maintenance of the genetic diversity of the species and also for breeding in search of characteristics of interest to the human being.

\section{References}

ARAÚJO, P. M.; NASS, L. L. Caracterização e avaliação de milho crioulo. Scientia Agrícola, v. 59, p. 589-593, 2002.

BÄNZINGER, M.; LONG, J. The potential for increasing the iron and zinc density of maize through plant-breeding. Food and Nutrition Bulletin. v.21, p.397-400, 2000.

BARROS, L. B.; MOREIRA, R. M. P.; FERREIRA, J. M. Phenotypic, additive genetic and environment correlations of maize landraces populations in family farm systems. Scientia Agricola. v. 67, p. 685-691, 2010.

BOUIS, H. E.; SALTZMAN, A. Improving nutrition through biofortification: A review of evidence from HarvestPlus, 2003 through 2016. Global Food Security. v. 12, p.49-58, 2017.

BRAZIL. Lei No 13.123, de 20 de maio 2015. Regulamenta o inciso II do $\S 1$ o e o $~ 40$ do art. 225 da Constituição Federal, o Artigo 1, a alínea j do Artigo 8, a alínea c do Artigo 10, o Artigo 15 e os $\S \S 3$ o e 4o do Artigo 16 da Convenção sobre Diversidade Biológica, promulgada pelo Decreto no 2.519, de 16 de março de 1998; dispõe sobre o acesso ao patrimônio genético, sobre a proteção e o acesso ao conhecimento tradicional associado e sobre a repartição de benefícios para conservação e uso sustentável da biodiversidade; revoga 
a Medida Provisória no 2.186-16, de 23 de agosto de 2001; e dá outras providências. Brasília, DF, 2015.

BROWN, W. L.; DARRAH, L. L. Origin, Adaptation, and Types of Corn. National Corn Handbook. 1985, 6p.

CAKMAK, I. Enrichment of cereal grains with zinc: Agronomic or genetic biofortification? Plant Soil. v.302, p.1-17, 2008.

CANCI, A.; GUADAGNIN, C. A.; GUADAGNIN, C. M. I. A diversidade das espécies crioulas em Anchieta - SC: Diagnóstico, resultado de pesquisa e outros apontamentos para a conservação da agrobiodiversidade. São Miguel do Oeste: Mclee, 2004, 112p.

CARVALHO, V. P.; RUAS, C. F.; FERREIRA, J. M.; MOREIRA, R. M. P.; RUAS, P. M. Genetic diversity among maize (Zea mays L.) landraces assessed by RAPD markers. Genetics and Molecular Biology. v.27, p.228-236, 2004.

CEVALLOS-CASALS, B. A.; CISNEROS-ZEVALLOS. L. Stability of anthocyaninbased aqueous extracts of Andean purple corn and red-fleshed sweet potato compared to synthetic and natural colorants. Food Chemistry. v.89, p.69-77, 2004.

COSTA, F. M.; SILVA, N. C. D. A.; OGLIARI, J. B. Maize diversity in southern Brazil: indication of a microcenter of Zea mays L. Genetic Resources and Crop Evolution, v. 64, p. 681-700, 2016.

DICKERSON, G. W. Specialty Corns. New Mexico State University. 2003. Available in: https://aces.nmsu.edu/pubs/_h/H232.pdf. Acess in July, 2020.

ERIKSSON, L.; JOHANSSON, E.; KETTANEH-WOLD, N.; WOLD, S. Multi-and megavariate data analysis. Principles and applications (2nd ed.). Umea, Sweden: Umetrics Academy. 2001.

FAO - Food and Agriculture Organization - Maize in human nutrition. 1992. Available in: $<$ http://www.fao.org/3/T0395E/T0395E03.htm> Acess in: June 2020.

FORD, R. Inheritance of Kernel Color in Corn: Explanations \& Investigations. The American Biology Teacher. v.62, p.181-188, 2000.

HARJES, C.E.; ROCHEFORD, T. R.; BAI, L.; BRUTNELL, T. P.; VALLABHANENI, R.; WILLIAMS, M.; WURTZEL, E. T.; KANDIANIS, C. B.; SOWINSKI, S.G.; STAPLETON, A. E.; YAN, J.; BUCKLER, E. S. Natural genetic variation in lycopene epsilon cyclase tapped for maize biofortification. Science. v.319, p.330-333, 2008.

HARLAN, J.R. Our vanishing genetic resources. Science, v. 188: 618-621, 1975.

HULSHOF, P. J. M.; KOSMEIJER-SCHUIL, T.; WEST, C. E.; HOLLMAN, P. C. H. Quick screening of maize kernels for provitamin A content. Journal of Food Composition and Analysis. v.20, p.655-661, 2007.

HWANG, T.; NDOLO, V. U.; KATUNDU, M.; NYIRENDA, B.; BEZNER-KERR, R.; ARNTFIELD, S.; BETA, T. Provitamin A potential of landrace orange maize variety (Zea 
mays L.) grown in different geographical locations of central Malawi. Food Chemistry. v.196, p.1315-1324, 2016.

JASWIR, I.; NOVIENDRI, D.; HASRINI, R. F.; OCTAVIANTI, F. Carotenoids: Sources, medicinal properties and their application in food and nutraceutical industry. Journal of Medicinal Plants Research. v.5, p.7119-7131, 2011.

KOUSHAN, K.; RUSOVICI, R.; LI, W.; FERGUSON, L. R.; CHALAM, K. V. The role of lutein in eye-related disease. Nutrients. v.5, p.1823-1839, 2013.

KUHNEN, S.; LEMOS, P. M. M.; CAMPESTRINI, L.H.; OGLIARI, J. B.; DIAS, P. F.; MARASCHIN, M. Carotenoid and anthocyanin contentes of Brazilian maize landraces. Journal of the Science of Food and Agriculture, v. 91, p. 1548-1553, 2011.

MAFRA, A. G. F. D. Zinc and cancer: a review. Revista saúde. v.1, p.144-156, 2005 MAQBOOL, M. A.; ASLAM, M.; BESHIR, A.; KHAN, M. S. Breeding for provitamin A biofortification of maize (Zea mays L.). Plant Breeding. v. 137, p.451-469, 2018.

MENKIR, A.; DIXON, B. M.; MENGESHA, W.; ROCHEFORD, T.; ALAMU, E. O. Accruing genetic gain in pro-vitamin A enrichment from harnessing diverse maize germplasm. Euphytica. v.213, p. 1-12, 2017.

MESSIAS, R. S.; GALLI, V.; SILVA, S. D. A.; ROMBALDI, C. V. Carotenoid Biosynthetic and Catabolic Pathways: Gene Expression and Carotenoid Content in Grains of Maize Landraces. Nutrients. v.6, p. 546-563, 2014.

MESSIAS, R. S.; GALLI, V.; SILVA, S. D. dos A.; SCHIRMER, M. A.; ROMBALDI, C. V. Micronutrient and functional compounds biofortification of maize grains. Food Science and Nutrition. v.1, p1-60, 2013.

NASS, L.L.; PELLICANO, I.J.; VALOIS, A.C.C. Utilization of genetic resources for maize and soybean breeding in Brazil. Brazilian Journal of Genetics, v.16, p.983-988, 1993.

O'LEARY, M. Maize: From Mexico to the world. CIMMYT - International Maize and Wheat improvement center. 2016 Available in < https://www.cimmyt.org/blogs/maizefrom-mexico-to-the-world/> Acess in: June 2020.

PATERNIANI, E.; NASS, E.; SANTOS, M. X. O valor dos recursos genéticos de milho para o Brasil - uma abordagem histórica da utilização do germoplasma. In: UDRY, C. V.; DUARTE, W. (Org.) Uma história brasileira do milho - o valor dos recursos genéticos. Brasília: Paralelo 15, 2000. p. 11- 42.

PILLAY, K.; SIWELA, M.; DERERA, J.; VELDMAN, F. J. Provitamin A carotenoids in biofortified maize and their retention during processing and preparation of South African maize foods. Journal Food Science Technology. p.1-11, 2011.

POMERANZ, Y. Grain Structure and End-Use Properties. Food Structure. v.1, p.107-124, 1982.

RODRIGUEZ-AMAYA, D. B. Carotenoids and food preparation: the retention of 
provitamin A carotenoids in prepared, processed and stored foods. Office of Health and Nutrition, U.S. Agency for International Development. Washington, DC, 1997.

SANDRI, C. A.; TOFANELLI, M. B. D. Milho Crioulo: Uma Alternativa para Rentabilidade no Campo. Pesquisa Agropecuária Tropical. v. 38, p. 59-61, 2008.

SCHULZ, H.; BARANSKA, M. Identification and quantification of valuable plant substances by IR and Raman spectroscopy. Vibrational Spectroscopy. v.43, p.13-25, 2007.

SWARNO, W. B.; PIXLEY, K. V.; ROJAS, N. P.; KAEPPLER, S. M.; BABU, R. Formation of Heterotic Groups and Understanding Genetic Effects in a Provitamin A Biofortified Maize Breeding Program. Crop Science. v.54, p.14-24, 2014.

SWELEY, J. C.; ROSE, D. J.; JACKSON, D. S. Hybrid and environment effects on popcorn kernel physiochemical properties and their relationship to microwave popping performance. Journal of Cereal Science. v. 55, p. 188-194, 2012.

TEIXEIRA, F. F.; Milho Cultivado no Brasil e banco de germoplasma - uma forma de classificação da variabilidade genética, EMBRAPA, Comunicado Técnico, 2008, 11p.

UARROTA, V. G.; AMANTE, E. R.; DEMIATE, I. M.; VIEIRA, F.; DELGADILLO, I.; MARASCHIN, M. Physicochemical, thermal, and pasting properties of flours and starches of eight Brazilian maize landraces (Zea mays L.). Food Hydrocolloids. v.30, p.614-624, 2013.

USDA - U.S. Department of Agriculture. FoodData Central. Available in:

https://fdc.nal.usda.gov/fdc-app.html\#/food-details/396830/nutrients. Acess in: June 2020.

VALLABHANENI, R.; BRADBURY, L.M.; WURTZEL, E.T. The carotenoid dioxygenase gene family in maize, sorghum, and rice. Arch. Biochem. Biophys. v. 504, p.104-111, 2010.

WHO - World Health Organization - Micronutrients deficiencies. 200? Available in:< https://www.who.int/nutrition/topics/vad/en/> Acess in: June 2020.

WURTZEL, E. T.; CUTTRIS, A.; VALLABHANENI, R. Maize provitamin A carotenoids, current resources, and future metabolic engineering challenges. Frontiers in Plant Science. v.3, p.1-12, 2012.

YAN, J. B.; KANDIANIS, C. B.; HARJES, C. E.; BAI, L.; KIM, E. H.; YANG, X. H.; SKINNER, D. J.; FU, Z. Y.; MITCHELL, S.; LI, Q.; FERNANDEZ, M. G. S.; ZAHARIEVA, M.; BABU, R.; FU, Y.; PALACIOS, N.; LI, J. S.; DELLAPENNA, D.; BRUTNELL, T.; BUCKLER, E. S.; WARBURTON, M. L.; ROCHEFORD, T. Rare genetic variation at Zea mays crtRB1 increases betacarotene in maize grain. Nat. Genet. 42, 322-327. 2010.

ZEVEN, A. C. Landraces: A review of definitions and classifications. Euphytica. v. 104, p. 127-139, 1998.

ZHU, C.; NAQVI, S.; BREITENBACH, J.; SANDMANN, G.; CHRISTOU, P.; CAPELL, T. Combinatorial genetic transformation generates a library of metabolic phenotypes for the carotenoid pathway in maize. Proc. Natl. Acad. Sci. v.105, p.18232-18237, 2008. 
JÚNIOR, et al.

ZUMA, M. K.; KOLANISI, U.; MODI, A. T. The Potential of Integrating Provitamin ABiofortified Maize in Smallholder Farming Systems to Reduce Malnourishment in South Africa. Environmental Research and Public Health. v.15, p.1-12, 2018. 